されている熱交換器よりも，優れている.

この結果に基づき，TM-3 型熱交換器を用いて行っ た臨床においても, 加温水側は, 流量 $13 \mathrm{l} / \mathrm{min}$, 温度 $45^{\circ} \mathrm{C}$, 血流量は $1.5 \ell / \mathrm{min}$ の条件で，体重 $60 \mathrm{~kg}$ の症 例に対し, 約 50 分で体温を，目的の $41.5^{\circ} \mathrm{C}$ まで上げ ることができる．このことは生体の高温に対する生理 反応を併せて考えると，理想的なヒーティングタイム といえる.

105 回の全身ハイパーサーミア療法で, 熱交換器に 基づく問題はなく，安全に施行できた。

\section{6. 薬剤注入用小型ディスポーザブルポンプ}

\section{北海道大 応電研MTR 部門}

田中志信 鷠津秀昭 柴田政広 山越畫一 神谷暸

演者らは前回の本学会において, 浸透圧を利用した 小型・軽量で簡易構造のインフュージョンポンプを考 案し, その動作原理および試作ポンプの流量特性等に ついて発表した. 本ポンプは駆動源として浸透圧を利 用しているため患者の心理的負担となる機械音の発生 が皆無であり，小型・軽量で携行にも支障が無く，さ らに簡易構造のため製作コストを低廉化できる等の特 徵を有している.今回演者らは簡易構造という特徵に 着目し，ディスポーザブル化可能なポンプのプロトタ イプを試作し，そのポンプ特性について検討した。一 方, 高抵抗膜としてのホローファイバ (H. F.) に着目 し，駆動源にバネを利用した小型簡易構造のポンプに ついても検討した。

[浸透圧駆動ポンプ】 今回試作したポンプはより簡 易構造とするためH. F. 本数を一定とし, 溶液濃度を変 えることにより流量を調節できるよらにした，ポンプ 本体の総重量は $50 \mathrm{~g}$, 形状寸法はほぼタバコケース大 で携行には支障が無い. 薬液量は $5 \mathrm{ml}$ としたが，使 用条件に応して種々の容量のものが用意可能である。 流出流量特性は長時間にわたり安定しており, 時閒経 過に対する総流出量の直線性も良好であった，流量の 負荷圧感受性は濃度に依存せずほぼ一定で，試作ポン プでは $-7 \sim 9 \times 10^{-3} \mu \ell / \mathrm{min} / \mathrm{mmHg}$ となり, 動脈内 投与手段としても十分実用に供しらるものと考えられ る.

〔バネ駆動ポンプ】 本ポンプは H.F.の高抵抗膜特 性を利用し駆動源としてバネ力を用いたもので，以下 にその動作原理を述べる．H．F．内部に水を澫たし，
この水にピストンと压縮コイルバネを利用して圧力を 加える. 水は圧力に比例した速度で H.F. の小孔を通 り外部へ流出するため, 外部の水の体積は一定速度で 微少量増加寸る。この体積増加を薬液に伝え長時間持 続注入を行らことがでさる，基礎実験の結果，流量安 定性, 負荷圧不感応性ともに良好で, 十分実用に供し 得ることが確認された。

\section{AAV における “Fighting Killer”}

東京女子医大 胸部外科

日野恒和笹生正人 山口明満中島秀嗣 長柄英男河村剛史

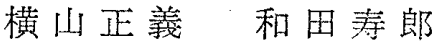
株アイカ

安立哲夫塚越太郎

Adaptive Assisted Ventilation (AAV)：順応性補 助呼吸は，以下の意味において，患者の自発呼吸にレ スピレータが順応する呼吸補助である。

(1) 患者の demand に応じて supply がなされる. (supply-demand relation の満足)

(2) 回路による気道抵抗が極小.

(3) 補助呼吸の際, response time delay がなく, 自 然な患者の自発呼吸に陽圧呼吸がスムーズに重畳 する。

(4) 患者の hypoxia, hyper eapnea など, demand の大きい時の呼吸補助はす早く，これらから回復 し, 呼吸補助が不要になる場合には，ゆっくりと 陽圧呼吸が減少するなど， supply timing の合目 的性が実現されている.

などである、そのため，レスピレータとの fightingは 極めて少ない，しかし皆無ではないので，これらの fightingを吸収してしまう機構を今回，新たに開発 し, “Fighting Killer”と命名し. AAVの 1 要素とし て組み込んだ. 原理は簡単で, fighting の際, 誘発さ れる哚い気道内陰圧もしくは異常気道内高圧のいずれ かを trigger として，その後一定時間陽圧呼吸を停止 し，乙かも呼気弁を開放位に保ち，気道を全くfreeに してしまうのである。この際吸気，呼気の気道抵抗と 十分減少する必要があり, 吸気時には constant flow, およびロもとの flexible reservoir など AAV 回路の 利点が生かされるが，呼氛抵抗減殺の意味で，新たに 呼気回路の直径を $3.5 \mathrm{~cm}$ とし，長さを $20 \mathrm{~cm}$ とした。 これにより従来 fighting の少ないAAVにとって，さ 
らに繊細な配慮が加わり，AAVを一段と洗練された ものにした。臨床治験も良好であった。

\section{8. $\mathbf{A A V}$ 組み込みレスピレータの試作}

\section{東京女子医大 胸部外科}

日野恒和中島秀嗣 筈生正人山口明満 長柄英男河村剛史 横山正義和田寿郎 橉アイカ

安立哲夫塚越太郎

順応性補助呼吸: Adaptive Assisted Ventilation (AAV) は患者の換気需要に応じて, 供給する陽圧呼 吸数が增減する，いわ㠴る supply demand relation を満足する。全く新しい概念の呼吸補助方式である。 従来は Bennet MA-1 や Bird Mark 8 など, 補助呼 吸の可能なレスピレータと, 波動せる constant gas flowを供給する装置とを連動させて行った. constant gas flow波動を与えるのは，これを吸入することに より, 吸気気道内圧を rondom 化し, 補助呼吸として トリガーされる率をほどよくバラつかせるためであっ た。 今回, これらレスピータと, AAV 装置を 1 つに まとめた新しいレスピレータを考案したので報告す る。このレスピレータの調節呼吸, 補助呼吸は従来の 従量式レスピレータとほとんど変わらないが，AAV に㧤いては, constant gas flow 飞波動を与えることは 行わず，代わりに補助呼吸に対するトリガーを漸増型 三角波形のくり返しとした。この三角波形の数 (AAV rate） 15 回/分 10 回/分 5 回/分 1 回/分の四段階 切り替光とした。角波形の頂上付近は最も鋭敏な卜 リガーであるため, AAV rate $n$ 回/分では, 毎分 $n$ 回のトリガーチャンスがあることになるが，患者の換 気需要に応して吸気気道内圧は增減するため, 実際に トリガーされる数は $n \pm \alpha$ となる。つまり $\alpha$ は患者 の換気需要に忘じて変化する幅であり, $n-\alpha=0$ の時 は automatic weaning も可能である。臨床例におい ていはさまざまに変化し，また補助呼吸の間隔は適当 にバラついており，理論ど抒りの AAVが行われた。

\section{9. 熱パルス移動型スパイロメータ}

東京医歯大 医用器材研

根本 鉄 戸川達男 水本尚吾土屋喜一

〔目的〕演者らは, 前回発表した熱移動型流量計を 呼吸機能検查用に実用化したので，その性能等につい て報告する。

〔湘定原理と装置の概要】流量の測定は，pulsed wire法の原理に基づき, 加熱用と感温用の, 平行に張ら れた 2 本の細線間を流体が通過する時間と断面積の関 倸によって求める。な拉従来の pulsed wire 法との相 違は, 感温用 wire が検出した感温信号を加熱用 wire にフィードバックして自励発振を起こさせ，その発振 周波数から流量を求める点である。

[結果と性能]上記のよらな自励発振の方法を採用 することにより，呼吸機能検查に必要とされる，0.02 $\ell / \mathrm{s}$ から $12 \ell / \mathrm{s}$ までの流量範围を安定に測定できるよ らになった。またトリガリング回路を付加することに よって, 努力性呼出開始直後の急激な流量変化に対し ても，およそ $20 \mathrm{msec} て ゙$ 答し，従来の熱線式流量計 と同程度の結果を得た。ガス組成による測定誤差も， $\mathrm{O}_{2},\left(\mathrm{O}_{2} \mathrm{~N}_{2}\right)$ 飞おいて， $\pm 2 \%$ の範囲に入っている. 直線性および再現性も土 $2 \%$ の精度範囲であった。

また，マイクロコンピュータを接続することによ り, 熱拡散等によって生じる非直線性の補正や，呼気， 吸気の連続測定, さらに低流量用センと高流量用セン サ併用時の切換え等を行わせた。

[結論】 測定流量範囲およびガス組成の影響および 応答時間の結果より，満足な值を得たことから本装置 は臨床用スパイロメータとして十分満足できることを 確認した。

\section{0. 新生児酸素療法の自動制御}

防衛医大校 医用電子工学
菊 地 真 関 昌 明
慶灾義塾大 理工学部電気工学科
福 與 喜 弘 佐 野 昭
東京電機大 工学部電子工学科
若月 浩 小谷 誠

〔緒言】 従来, 新生児の呼吸障害を予防するために 保育器内酸素療法が行われてきた。 しかし長期にわた り酸素を高濃度に保つと, 血中酸素分圧が異常に上昇 